\title{
"Don't worry": Figurations of the child in a Swedish parenting advice column.
}

Peter Skagius

The self-archived postprint version of this journal article is available at Linköping University Institutional Repository (DiVA):

http://urn.kb.se/resolve?urn=urn:nbn:se:liu:diva-163095

N.B.: When citing this work, cite the original publication.

Skagius, P., (2019), "Don't worry": Figurations of the child in a Swedish parenting advice column., History of Psychology. https://doi.org/10.1037/hopoooo138

Original publication available at:

https://doi.org/10.1037/hopooo0138

Copyright: American Psychological Association

http://www.apa.org/ 


\section{Abstract}

Materials such as popular books, magazines and newspapers have historically been important for the circulation of psychologists and psychiatrists' expertise in the public sphere. In this paper I analyze an advice column published in the Swedish parenting magazine Vi Föräldrar (Us Parents), featuring the child psychologist Malin Alfvén. Drawing on the concept of figurations (Castañeda, 2002), denoting the process of outlining and defining an entity, I show how the expert framed the child-related problems brought up in the submitted letters as transient and a normal part of children's development. In fact, most problems were considered beneficial for both parents and child. Instead of interpreting children's behavior through a medical framework, Alfvén's explanations drew on three naturalizing figurations of the child: as being one of several kinds of children; as going through phases and ages; and as being a unique individual. For instance, a child could be rowdy and temperamental because he was a willful kind of child, not because, as suggested by some parents, he suffered from a neuropsychiatric disorder. I conclude by contrasting these findings to the claims made by some scholars that 'psy' experts have contributed to an increasing medicalization of childhood as well as to a framing of children's development as overwhelmingly determined by parents' care.

Keywords: History of child psychology; popular psychology; parent advice; childhood studies; Sweden 


\section{"Don't worry": Figurations of the child in a Swedish parenting advice column.}

In this article, I analyze an advice column in the Swedish parenting magazine Vi Föräldrar (Us Parents) in which a child psychologist answered questions sent in by readers. The material, which covers the issues published in 2003-2008, offers a valuable opportunity to trace the mediated interactions between readers and the expert since the submitted questions and the expert's answers were published side by side. The article's analytical focus can further be highlighted against the backdrop of the extensive body of historical scholarship charting the influence of "psy" experts (Rose, 1991) on childhood matters (e.g. Beatty, Cahan, \& Grant, 2006; Börjesson \& Palmblad, 2003; Rose, 1999). Although this strand of research has certainly yielded important insights, it has been characterized by a general bias towards examining professional and scientific literature (Thomson, 2006). But the "success" of the "child psy" disciplines should also - if not to an even greater extent - be attributed to the wide circulation of popular material, for instance, magazines and newspapers, presenting "psy" expertise to the public (see e.g. Quirke, 2006; Wall, 2018; Ward, 1996; Wrigley, 1989). Moreover, the value of analyzing public material can be underscored in relation to Pettit (2015, p. 147), who argues that there is a need for a "greater specificity about psychology's impact, better evidence of the circuits between expert description and self-understanding, and appreciation of the complicated lives of scientific methods and theories." Accordingly, to better understand and theorize the influence of "child psy" experts and the complex circulation of their knowledge, we must look beyond the confines of professional and scientific literature, as I do here.

In my analysis of the advice column, I draw on the concept of figuration, as articulated by childhood scholar Claudia Castañeda (2002), to show how Malin Alfvén, the child 
psychologist writing the column, consistently reframed the problems of children presented by letter-writers as transient and natural consequences of the child's development. They were thus interpreted through a naturalizing, rather than a medical or psychiatric, framework. Moreover, Alfvén's reframings were found to be underpinned by three ways of defining - or, in this article's vocabulary, three figurations of - the child that served to explain children's behavior: the child as one of several Particular kinds of children; as Going through phases and ages; and as being a Unique individual. Each figuration implies different understandings concerning such aspects as whether all children follow a similar developmental trajectory. Although each figuration thus has specific, and somewhat contrasting, implications for how to understand children's health and development, in the column the figurations appeared side by side without any apparent contradiction.

This article argues that Alfvén's figurations are particularly intriguing in the light of historical research detailing how experts' conceptualizations of childhood and children changed in the West during the $20^{\text {th }}$ century. This scholarship has stressed that children have increasingly been discussed as fragile and almost constantly at risk from various social, environmental, technological and developmental dangers (Clarke, Mosleh, \& Janketic, 2014; Hardyment, 2007; Stearns, 2003; Zetterqvist Nelson, 2017). This emphasis ties into the notion of "parental determinism" (see Lee, Bristow, Faircloth, \& Macvarish, 2014, although they approach the notion from a primarily sociological, rather than historical, angle), denoting a perspective from which the child's development mainly depends on the parents, increasing the pressure on parents to provide optimal care informed by scientific expertise.

These conceptual and discursive transformations are claimed to have led to a devaluation of parents" "folk" knowledge and a transformation of "the relationship between a parent and a child into a set of skills that has to be learned and acquired [from experts], and for which instinct provides no satisfactory guide" (Lee, 2014, p. 53). Alfvén differed markedly from 
this trend, instead espousing a view in which children are quite sturdy, resilient and selfcorrecting. Parents' care did not determine most aspects of their child's development, nor did they have to acquire any special competence in order to be good parents. They were instead generally encouraged to have patience, feel confident in themselves and wait for their child's development to unfold by itself.

The aim of this article is to nuance and complicate these broad historiographical claims about children, childhood and "psy" experts - for instance, the role attributed to the latter in emphasizing "parental determinism"- and to make room for more precisely situating the circulation of "psy" expertise within particular networks that reach specific publics. While one person may encounter medicalized advice about fragile children, another may read an advice column such as Alfvén's and discover a completely different set of ideas and practices. I hope this makes it clear that my goal is not to refute these broad historiographical claims in toto (nor is it possible to do so, based solely on an analysis of a single set of advice columns). This article should rather be viewed as offering a complementary, and enriching, contribution to this ongoing historical strand of research.

As evidenced above, this article also aspires to bring the history of the "psy" sciences and the history of childhood closer together, as they have often led separate lives despite, in my view, having much to say to each other. This ambition is here represented through mingling literature from both fields as well as using an analytical vocabulary drawn from historical work on childhood. This ambition will be further evident in my concluding discussion, where I provide a contextualization of Alfvén's figurations and relate them to historical studies on both the "psy" sciences and childhood.

In the middle of the $18^{\text {th }}$ century advice regarding children's health and development was first marketed toward the general public, instead of to authorities such as doctors (Hardyment, 
2007). This early form of advice often urged mothers to listen to their instincts and follow the child's natural inclinations. A significant change occurred around the turn of the $20^{\text {th }}$ century, with the emergence of the "scientific motherhood" movement, which stressed the need for expert knowledge on childhood matters (Apple, 2006), and the onset of an intensified scrutiny of the psychological and psychiatric aspects of childhood, as exemplified by the widespread Child Study Movement (Sandin, 2014). These historical developments paved the way in many Western countries for child experts and made their knowledge an accepted though not undisputed - reference for curious, interested and anxious parents. Following this, $20^{\text {th }}$ century experts used various media channels to reach out to the public, underlining the importance these had for the circulation of "child psy" expertise. To give some examples, in Britain, Donald Winnicott frequently featured in BBC radio broadcasts, while Susan Isaacs popularized the theories of Melanie Klein in the journal Nursery World (Shapira, 2013, 2017). Even John Bowlby relied on writing in the popular magazine Parent to spread the nowadays very influential - theory of children's attachment to their caretakers (Thomson, 2013). Likewise, in North America, influential childcare experts such as Benjamin Spock and Arnold Gesell gave public talks and wrote popular-scientific books and pamphlets (Hulbert, 2004).

In this advice literature it is possible to discern two broad trends. The first, which is often given prominence in especially the North-American context, is that experts have consistently told parents that they must adhere to expert advice if they are to bring up healthy, wellfunctioning children (Wrigley, 1989; Gleason, 1996a). This message, as mentioned above (but see Hardyment, 2007 and Stearns, 2003 for details), has been partly underpinned by an increasingly prominent framing of the child as a fragile being whose development is continuously at risk of being disturbed or impaired. Juanne Clarke and colleagues have conducted several historical studies of magazines (Clarke, 2011, 2014; Clarke et al., 2014) 
and have similarly found a strong emphasis on the need for parents to consult with medical and psychological experts and on the responsibility that parents, particularly the mother, have for managing childhood risks. This is not unique to the North American context, however. Studies analyzing Swedish television shows from the 2000s that featured child experts have likewise found frequent claims that parents have a responsibility for, and a strong effect on, their child's health, development and conduct (Assarsson \& Aarsand, 2011; Dahlstedt \& Fejes, 2014; a similar message has been conveyed by Swedish healthcare professionals, see Hörnfeldt, 2009).

In the second trend, although much of the literature argues that experts have predominantly framed childhood as fragile, at risk and in medicalized terms, this dominant picture has not gone completely unchallenged. Clarke (2010, p. 177) found that one parenting magazine presented advice that instead normalized "health issues as minor inconveniences" manageable by the mother. Social and political causes of children's mental ill-health have also been highlighted, as found in an analysis of magazines aimed toward African-Americans (Clarke \& Mosleh, 2015). Although not solely focusing on childhood, Sofia Seifarth (2007) has analyzed a popular Swedish radio show of the 1950 s and ' 60 s in which the counselor Lis Asklund used a "diluted" psychoanalytic vocabulary to frame and normalize the occurrence of psychological disturbances. Bowlby's advice in Parent similarly took a "mediated, diluted form, presented as common sense rather than theory, and with a greater degree for flexibility than isolated statements ... might suggest" (Thomson, 2013, p. 90). Albeit not as prominent in the literature as the medicalized, "riskified" framing of the child, these findings help to outline a broader spectrum of explanatory frameworks and theories, ranging from a medicalizing to a more normalizing approach that presents itself as relying on common sense, and not abstract theory, and where child-related problems are posited as mainly nonmedical in nature. 
Finally, I want to mention two studies of Vi Föräldrar, even though they do not focus solely on "child psy" experts. Möllerström, Sandberg and Ringsberg (2013) found that the magazine addressed readers in an empowering tone which underlined that parents should trust themselves and their capabilities. Experts often featured in articles, but they presented their views on children and childhood in a tentative manner. Children were also framed as active subjects who were not subordinate to their parents. Thomas Johansson (2007) conducts an historical analysis of the magazine, focusing on the 1970s onward. One finding particularly relevant to this article is that, like Möllerström et al. (2013), Johansson discerns how, over the years, the child was increasingly discussed as a competent and active individual, even from a very young age.

In light of this overview, this article contributes on several levels. Although both Möllerström et al. (2013) and Johansson (2007) studied Vi Föräldrar, they considered a wide range of questions and interests. In this article, I focus more narrowly on a single set of advice columns in order to comprehensively analyze the "child psy" expert's answers. This allows for greater empirical and analytical detail as well as situating the analysis more firmly in the history of psychology and psychiatry. This article also places stronger emphasis than much of the previous literature on the mediated interaction between parents and the expert because the magazine published both the parents' questions and the expert's answers. The "translational" process between the parents' descriptions and the expert's proposed solutions can thus be clearly analyzed, enabling a fuller understanding of how the expert framed and interpreted the child-related problems presented by parents. Finally, the analysis and contextualizing discussion draw on both the history of the "psy" sciences and the history of childhood, in line with the article's aim of bringing these fields closer together. 


\section{Figurations}

In analyzing the material, I draw on Claudia Castañeda's (2002) concept of figurations. A figuration is the material and/or semiotic process "by which a concept or entity is given particular form" (2002, p. 3). Following Castañeda (2002, p. 5), a focus on figurations of the child can locate "purportedly general claims concerning the child in particular discursive, cultural and geopolitical contexts." I argue that it is particularly important to understand the relation between the semiotic aspects of figurative processes - e.g. how the figure of the child is defined - and the material dimensions, i.e. through which materialities the figurative practices take place, and where. The concept of the figuration thus underlines both how the child is semiotically demarcated and the medium through which this occurs; for example, here, through a parenting magazine's advice column that is delivered to people's homes or read at child health clinics.

The concept is also useful because, as Castañeda (2002) argues, the child figure accumulates power and value precisely through its multiple, partly overlapping figurations. My starting point was therefore not to assume that there was necessarily a singular figure of the child discernable in the advice column, even though it was written by a single psychologist and published in the same magazine over a rather short range of years. Rather, I conducted an open, exploratory analysis of how the child psychologist defined, discussed and framed the child. This approach, I argue, can help to destabilize broad, uniform figurations of the child, regardless of whether these are framed as repressive (e.g. "the medicalized child") or optimistic (e.g. "the authentic, natural child"). The concept allows me to instead examine and interrogate a diversity of figurations and clarify their interrelationships, without positing a universal, general figure of the child as a backdrop.

The overall ambition of this article is thus to shed light on the circulation of "child psy" expertise in the Swedish public sphere through highlighting how children and their perceived 
difficulties have been figured in a Swedish parenting magazine. Concretely, this translates into a two-fold focus in the analysis. First, how did the questioner describe their child and what was presented as the problem(s)? Second, how did the expert translate and figure the problem and what possible solutions were offered? The central analytical questions are: were there recurrent ways of figuring the child and, if so, what implications did these have for how to understand children and their problems?

\section{Vi Föräldrar}

Vi Föräldrar (henceforth VFö) was founded in the late 1960s, making it Sweden's oldest parenting magazine (Bonniers Tidskrift, n.d.). Its ambition was to promote an understanding of the child as an individual (Hedman Bergström \& Duregård, 2009). It has consistently been one of the most popular Swedish parenting magazines, with a circulation of 54200 and a monthly reach of 178000 in 2008 (Richter \& Ursholm, 2009). ${ }^{1}$ According to Möllerström et al. (2013), the magazine's articles have been characterized by a factual and balanced tone, with experts often commenting on the various subjects. The magazine has often been placed in the waiting rooms of Swedish child health clinics which, besides increasing its reach, has lent it legitimacy in discussing child health questions that "most other [magazines] cannot aspire to" (Möllerström et al., 2013, p. 61). Altogether, VFö is an interesting and important magazine to examine, particularly due to its position in the Swedish media landscape and its gravitas in questions concerning children's health and development.

This article forms part of a research project studying the history of the "child psy" sciences in the Swedish media and press, 1968-2008. I have therefore examined issues from each of these four decades. However, in this article, I focus solely on 2003-2008. The 2000s were a period when Swedish children's mental health and development were intensely debated and

\footnotetext{
${ }^{1}$ For some points of comparison, in 2008 Sweden had a population of around nine million. In the same year, the reach of Sweden's largest morning paper was around 350000 while the largest evening paper had around 460000 readers.
} 
problematized. During this period, there was a shift in the Swedish public debate toward more neuropsychological ways of describing our understanding of children's psychological health (e.g. Skagius, 2019) as well as several critical reactions to this shift (e.g. Kärfvé, 2000). This period also saw several public reports that grappled with questions concerning Swedish children's and youth's (seemingly deteriorating) mental well-being (e.g. Bremberg, 2006; Socialstyrelsen, 2004) and Swedish politicians debated how educating parents could improve the mental health of the country's children (Littmarck, 2017). It is thus of great interest to consider the discussions of children's health and development that "child psy" experts offered to Swedish parents during this period. The issues of VFö published in $2003-$ 2008 featured an advice column dedicated to questions concerning child psychology, providing a rich source of empirical material to analyze, while the shorter range of years still keeps the amount of material manageable.

From 2003 to 2007 there were 13 issues published each year, with 14 in 2008 . The magazine featured articles on children's physical, social and emotional development; specific childrelated problems and how parents could handle them, such as infants having trouble sleeping; gender and parenting; pregnancy and childbirth; tests of children's clothing and toys; and activities and travel that parents could engage in with their children. There were also some recurring features, such as letters to the editor, submitted pictures and advice columns. Each issue included two advice columns: Fråga oss (Ask us), in which different professions, such as a doctor, a gynecologist and the editor, answered questions, and Fråga Malin (Ask Malin), which featured the child psychologist Malin Alfvén (see Figure 1 for a reproduction of the column).

[Insert Figure 1 here]

Figure 1. The advice column Fråga Malin, reproduced from Vi Föräldrar, 2005, 4, p. 98. 


\section{Malin Alfvén and the advice column}

Alfvén started working clinically with children and parents in the early 1970s and began answering questions in $V F \ddot{~ i n ~ t h e ~ e a r l y ~ 1990 s . ~ S h e ~ h a s ~ w r i t t e n ~ s e v e r a l ~ b o o k s, ~ s u c h ~ a s ~ O r o n ~}$ som gör oss till bättre föräldrar (The worry that makes us better parents) and Tagga ner! Lagom bra föräldrar är bäst (Cool down! Good enough parents are the best), several of which build on her work in $V F \ddot{o}$. Her books have been in high demand and have been reprinted repeatedly. Trotsboken (The Defiance Book), for instance, appeared in its fourth edition in 2015, while others have been translated into Danish and Estonian. Alfvén was also one of the experts answering listeners' questions on the program Knattetimmen (roughly: The Tiny Hour), which ran for several years on nationwide Swedish public radio and whose questions and answers were turned into a book as well.

While all of this demonstrates her broad and enduring public appeal, Alfvén's expertise has also been acknowledged by the professional community. In 2011, she received Stora psykologpriset (the Grand Psychologist Prize). The jury stated that:

Malin Alfvén has been, as the nominating parent put it, "a candle in the dark," working with both her own patients and for the public through advising in books, magazines, radio and TV. By helping both children and adults to understand that you don't have to be perfect to be a good parent, during her thirty years as a psychologist she has dared to challenge our society's attitudes toward the parenting role. (Norstedts, n.d.)

The president of the Swedish Psychological Association noted at the time that Alfvén "has helped thousands of patients, listeners and readers to tackle the challenges of parenthood and spread knowledge to the public about the parental role" (Psykologtidningen, 2011). 
Alfvén's high level of productivity, extending over several decades, means that she has had the potential to reach, and possibly influence, a large number of Swedes. Her expertise has furthermore been acknowledged and prized by her psychology colleagues. It is for these reasons that I have chosen to focus on Alfvén. I would even argue that some of her influence can be attributed to her personal tone and relation to the public, as evidenced by the title of her column, which features her first name.

The questioners writing to Alfvén often used pseudonyms, such as "Grateful for an answer" or "Nillan's mother," making it difficult to draw any general conclusions regarding who was writing to the magazine. Neither have I been able to gauge how many letters Alfvén received nor how many of these she actually answered. Nevertheless, during the years covered by this study, a total of 226 pairs of questions-and-answers were published. The questioners' signatures and the brief biographical information sometimes given suggest that most of those writing to the magazine were female. The descriptions of the children varied in length but generally specified the child's gender and age, the latter ranging from just a few months to upward of ten or eleven years. Most of the children, however, appeared to be between six months and six years of age. The published questions mostly revolved around a recurring set of themes: how to handle physical needs (how to get the child to sleep or use the toilet); transitional events or periods in the child's life, for instance, helping the child to start daycare; behavioral issues, such as children biting other children; and what might be called parenting worries, among them concerns that the parents were working too much.

After reading all the issues published during the chosen years, I created a chronological index in which I summarized each issue's advice column, noting what the questioner asked, their description of the child and their problem, and how the psychologist responded. I then went through the answers and looked for instances where the expert repeatedly defined and discussed - or using Castañeda's (2002) term, figured - the child in a particular manner (e.g. 
the child acted in this way because they were going through a developmental phase). Based on this review, I compiled an analytical index in which the question-and-answer pairs were sorted under each relevant figuration. The discerned figurations are presented in the following analysis as individual sections.

Before presenting the analysis, I offer some caveats. The submitted letters may have been editorialized, including selecting questions that suited Alfvén's interests and perspective. In addition, the advice in many parenting books, magazines and broadcasts is often marketed toward a particular segment of society, i.e. middle-class parents (Quirke, 2006). Finally, we cannot assume that experts' recommendations and suggestions were followed to the letter by parents in the actual, day-to-day care of their child (Mechling, 1975).

Yet there is still value, as contended by Gleason (1996b) and Milkie and Denny (2012), in analyzing material aimed at parents because the theories, explanations and norms conveyed by experts still function as reference points that people draw upon, despite not necessarily believing all of them in their entirety. And although the questions published in the magazine may have been selected to benefit Alfvén and the understanding of childhood and children's problems that she wanted to promote, my aim here is not to evaluate whether the magazine presented a "biased" view on the issues. Rather, I am interested in the "public" side of this process, that is to say, in what was actually presented to readers, regardless of what may have happened during the opaque editorial process.

Several figurations of the child are discernable in Alfvén's answers to parents: that there are Particular kinds of children, that children can go through Phases and ages, and Children as unique individuals. Before discussing these in detail, I first want to address how they related to Alfvén's thoroughgoing tendency to frame any problem as transient and ordinary. She explained almost all the child's distressing behaviors or worrisome emotional expressions as 
traceable to the vicissitudes of the child's natural development. In other words, the behavior was something quite expected and normal and not a sign of any psychological or psychiatric disorder. This reasoning was in turn underpinned by the three figurations of the child, which each provided grounds for a naturalizing and normalizing explanation. For instance, the physically active, temperamental and at times quite angry child was not thought to have a neuropsychiatric disorder. She might instead merely be one of those willful kinds of children who want to decide everything for themselves. Or it could be because she was going through a defiant phase. Such reframings were a significant characteristic that informed Alfvén's entire way of figuring the child and their problems.

\section{Defining children's problems as transient and natural}

A recurring feature of Alfvén's answers was her claim that the child's seemingly troublesome behavior was in fact beneficial and healthy. "Worried mom" requested advice on how to handle her temperamental seven-year-old son who became self-destructive when angry, often saying that he was bad and wanted to die. Was this a sign of depression, or at least a serious call for attention, the mother wondered. "Some children are harder to be a parent to than others" (VFö, 2004, 9, p. 84), Alfvén declared, but whether it was truly serious depended on where and when the son acted like this. If it only occurred at home, this showed that the boy knew he could safely share his anger and disappointment with his family. The parents thus only needed to seek help if he behaved in this way outside the family context. This example illustrates one way in which Alfvén "downgraded" the problems presented by parents, instead offering a more positive interpretation in which the child's perceived issues actually meant that they felt safe and understood.

Alfvén similarly refigured situations in which the child "provoked" the parent as essentially beneficial for both parent and child. "Farmer" expressed remorse that their hot temper often led to clashes with their oldest son, who was described as "unusually active and defiant" 
(VFö, 2003, 6, p. 107). The letter-writer asked for advice on how to avoid such confrontations and raised the risk of these impacting upon the son's development. In her reply, Alfvén stated that the parent's anger actually helped the son and explained that "he 'demands' from you that you shall stop his defiance and stubbornness, because he himself cannot manage all his feelings." She contended that the son dared to challenge his parents precisely because he felt safe knowing that they would push back.

How Alfvén dealt with questions concerning diagnoses is also worth considering, especially in light of claims about childhood as increasingly medicalized and psychiatry-dominated (see e.g. Billington, 1996; Timimi, 2014). Child developmental diagnoses, such as autism, have frequently appeared in other Swedish media contexts (Börjesson, 1999; Skagius, 2019). Alfvén herself never raised the topic of a child having a potential diagnosis but there were some instances when the inquiring parent brought it up. In all these cases, Alfvén disregarded the idea that a diagnosis was the primary solution. For instance, the signatory "Sad" described their four-year-old daughter as strong-willed, precocious and curious but also as emotionally volatile and easily angered. The daughter had "tried their patience to the limit" $(V F \ddot{o}, 2007,6$, pp. 114-115) and they wondered if she could have "some form of diagnosis [bokstavsdiagnos] $]^{2}$ ?" Alfvén doubted this and instead argued that the daughter was an "early developed little girl," in the middle of an important developmental period. Nevertheless, if the parents felt worried, they could contact a psychologist to discuss their concerns.

Alfvén likewise disagreed with "My hope rests on you...", who asked if their seemingly very angry and active child could have ADHD. Alfvén remarked that the boy challenged his parents because he felt safe enough at home to show his true, strong emotions. Furthermore, his behavior was typical of "stubborn, strong-willed and demanding children" (VFö, 2005, 4,

\footnotetext{
${ }^{2}$ Bokstavsdiagnos, literally translated as "letter diagnosis," is a Swedish expression denoting neuropsychiatric diagnoses such as attention deficit hyperactivity disorder (ADHD) or autism.
} 
p. 98; see also Figure 1) and the fact, stated by the parent in the letter, that he got on well in daycare went against the hypothesis of ADHD. Here as well, Alfvén suggested that if they still felt perplexed the parents could write or talk to someone, like a psychologist.

Alfvén's recommendations to seek outside help mainly suggested that parents could contact child psychiatric services to have someone to talk to about their concerns, not primarily to determine whether the child had a diagnosable disorder. The general absence in Alfvén's answers of diagnostic terms, or of any mention of the value of a diagnosis, can partly be related to her overall normalization and naturalization of children and their health, because a diagnosis could indicate the presence of a pathological entity or process that would seemingly disturb the notion of the child's natural developmental unfolding.

I have now discussed how Alfvén consistently refigured the problems and issues that seemed to be worrying parents. The "bad" or "disquieting" things their children said and did were not as serious as parents thought; frequently they were even a testament to the child's well-being. For instance, a son incessantly angered his parent because he knew deep down that he could rely on their anger to regulate his own overwhelming feelings. The parents' anger did not therefore indicate a lack of control on the parents' part nor was it harmful to the child; rather, it helped him grow and come to terms with life. Through Alfvén's refigurations, the seemingly problematic behavior of both the child and the adult was transformed into mutually enriching interactions that demonstrated their shared love and trust.

Instead of explaining children's perceived issues and problems in theory-laden and diagnostic terms, Alfvén's answers built on the three figurations of the child. This can be clearly seen in the response to "My hope rests on you..." where Alfvén rather dismissed the notion of the child having an ADHD diagnosis and argued that he was simply a strong-willed child. The child's behavior was not explicable by referring to a potential diagnosis but by understanding 
that the child was a particular kind of child. In the following section, I show how these three figurations can be analytically discerned in Alfvén's answers to her questioners.

\section{Figurations of the child}

\section{Particular kinds of children}

In this figuration, children's seemingly troublesome behaviors, conflicts and tendencies were framed as natural consequences of the kind of child an individual is, with each kind having their own characteristics and constitution. In general, Alfvén figured two kinds of children, the shy, sensitive child and the willful child.

The figuration of the shy, sensitive child can be discerned, for example, in the answer given to "Worried," who wondered how they could encourage their three-year-old daughter to be more talkative, as she was chatty at home but otherwise shy and quiet. Alfvén emphasized that "shy children are fantastic children. Shy children need to be cared for. ... The best for shy children in unknown situations is to stand at a slight distance and observe the world ... They are part of everything they see, but somewhat from the outside" (VFö, 2003, 11, p. 99). Let the child be shy, she argued, because shyness can also be an asset as these children often become journalists, actors or writers.

The implications of a sensitive constitution were also touched upon in the response to "Pretty tired mom," whose 13-month-old daughter had trouble sleeping and often woke in the night screaming. The mother had resorted to letting her daughter flail angrily in the parents' bed until she fell asleep from exhaustion. "[H]ow fantastic," Alfvén exclaimed, "that we parents can endure getting our sleep disturbed ... through pure love of our kids," and explained that her hypothesis was that the daughter was "an alert, curious and sensitive little person who takes in most of what happens around her during the day" (VFö, 2008, 14, p. 102). Such 
children dream more than others and will therefore also wake up more often, with a need to be close to their parents.

Overall, Alfvén stressed that parents needed to respect the shy and sensitive child's needs and inclinations. The child should not be forced to interact with others; they would learn just as much by observing the hustle and bustle and processing these experiences afterwards. The child's shyness was not a problem that had to be cured or corrected, as some parents seemed to think. On the contrary, Alfvén even presented it as a gift that made these children creative and empathic. Their parents needed to be receptive and adaptable to this constitution, even though it could be exhausting or worrisome.

The other repeatedly figured kind of child was the strong-willed, stubborn child. These children, as Alfvén stressed to "Grateful for tips," are "wonderful children" but "they challenge us parents and make us think and do things we never imagined" (VFö, 2004, 11, p. 102). Parents, Alfvén explained, should teach such children that they do not always get to decide, but still "let them protest." This would strengthen the child's own capacity by imparting to the child an understanding that "we know that they can handle that we decide." Yet this was not the only way to handle the stubborn child. The five-year-old son of "Panicked mom" was described as very picky about food, sometimes even throwing up when pressed to eat food he disliked. Alfvén stated that this was a matter where parents should not quarrel with "these incredibly stubborn and strong-willed children" (VFö, 2005, 9, p. 88). Instead they should "tell him that you intend to stop fighting and that from now on he will solely get to eat his favorite food." This would in the long term make the child curious to try other foods.

Alfvén again raised the tenacity of these children in her answer to "Perplexed mom," whose six-month-old son had trouble falling asleep. Children who have trouble sleeping, according 
to Alfvén, are "often very strongminded", they do not want to fall asleep and miss "anything that happens, they are intensely occupied with living and want to control their own lives" (VFö, 2003, 1, p. 63). These children are "conservative" and like to stick to what works for them. The parents were advised to help the child fall asleep by "stubbornly offering him other ways ... that suit the entire family." In the end, "he will go along with it," but she warned that it would take time and willpower on the parents' part.

The main approach for parents to handle these resolute children, which resembled the approach taken with shy ones, was to recognize that the child was acting in this way because they were a particular kind of child and that the perceived problems were caused by their constitution. But, in contrast to the mostly flexible parent of the shy child, the stubborn child sometimes had to be met by an equal amount of obstinacy. The child's willfulness had to be acknowledged, but not allowed to go wholly unchallenged.

As shown here, one way in which Alfvén explained children's behavior and functioning was to refer to the notion of different kinds of children, each with their own set of needs and tendencies. Her labeling of children as willful or shy is similar to the American pediatrician T. Berry Brazelton's portrayal of children as being of a shy, average or active kind (Hulbert, 2004). But, I would argue, Alfvén's figuration echoes constitutional theories in which a child's development and behavior is thought to be primarily determined by inner, often biological factors - in short, "nature" - which are not affected by the child's environment (Turmel, 2008). Alfvén presented the kinds of children as more-or-less permanent, set in stone from birth, in contrast to Brazelton's kinds, which seemed more dynamic. In Alfvén's case, parents simply had to acknowledge and adapt to the kind of child they had if they were to better understand why problems could occur and what to do about them. This figuration contrasts with the historically strong emphasis in developmental psychology on the significance of the child's environment (cf. Burman, 2008). 


\section{Children going through phases and ages}

Figuring children as being of different kinds meant that they were constitutionally predisposed to be and behave a certain way. However, children were also repeatedly figured in the advice column as going through phases and ages that affected their development and functioning, leading to large variations in behavior depending on the child's current phase. These passing stages could then, according to Alfvén, explain why, for instance, a child might suddenly become prone to anger and start acting out. This figuration offered an alternative account of children's problems that attributed them to transient developmental periods, not constitutional factors. Generally, however, these periods were not clearly specified in terms of years or duration (in contrast to early- $20^{\text {th }}$-century experts' attempts to precisely calculate the "ages" of children; see Beauvais, 2016). Instead, the phases and ages were relatively broadly defined and could largely be distinguished on the basis of behavior.

Alfvén frequently referred, especially in connection with letters describing children as rowdy or temperamental, to the defiant ages (trotsåldrarna; also the subject of a book of Alfvén's, 2001): "periods when we develop and mature more than otherwise" (VFö, 2007, 1, p. 85). When the signatory "Ida" asked for help regarding her 14-month-old son, who had suddenly become easily angered and prone to screaming, Alfvén replied: “Oh well, so it’s time! Now your life begins with the rebellious defiant periods ... Your son thinks that it's he who can control what happens in life, but you must intervene and show what's right and wrong" (VFö, 2007, 11, p. 112). Although it would be tough for them both, "without frustration and resistance we do not develop." Eventually everything would calm down - "[f]or a while ... until the next defiant period occurs."

Another letter-writer, "Tired but grateful mom," received a similar reply when she asked for advice on how to handle her two-year-old son, who was "fantastic" but "wild like few others" (VFö, 2003, 4, p. 113). The questioner was very appreciative of her son but thought that 
perhaps her "conceptions about having a child have not really corresponded to the reality experienced thus far." Alfvén replied that, even though many parents think they are in control, it is often actually the child who runs the show. This is particularly true while the child is going through one of the defiant periods, as was the case here, according to Alfvén. Despite the child being difficult and demanding, parents had to be firm and teach the child "to listen to others, to help others [and] that there is not just one person who should decide in a family."

Besides the defiant ages, Alfvén also outlined other phases and stages. One of these encompassed how children start to perceive their position in the world differently, which can lead to fears and upsetting fantasies. The five-year-old daughter of "Concerned mother" had started to have nightmares that made her afraid to fall asleep and she now insisted on sleeping in her parents' bed. "The probable [cause]" Alfvén explained, "is that she is in a transitional phase in life" $(V F \ddot{o}, 2007,10$, p. 104) that simply had to be passed through. The child now realized her vulnerability and reliance on her parents' protection, progressing from the developmentally earlier view that she was "invincible and the world was hers. Now she is starting to look the dangers of life straight in the eye and is haunted at night by monsters." The signatory "Thanks in advance," who did not know what to do with their five-year-old son who had suddenly become scared of everything, received a similar explanation. Children of that age go through a lot, Alfvén responded, with many becoming easily scared because they "have really started to understand how dangerous the world is and how small and exposed you are as a human" (VFö, 2008, 11, p. 121). Although this phase meant that the child could become fearful, in the end, in Alfvén's way of figuring the process, it would also further their development. 
Another phase mentioned by Alfvén also revolved around the experience and expectation of omnipotence, both the child's and the parents'. "Worried mom" could not understand why her one-year-old son had started screaming and protesting as well as snatching toys from other children. This change in behavior, Alfvén noted, was a result of the son realizing that he "is not the center of the world" (VFö, 2004, 4, p. 100). This was a phase every child had to go through, but stubborn children had an especially difficult time during this period, which had an impact on the parents as well. Similarly, the five-year-old daughter of "Mother of two" could be sitting at the computer and then suddenly yell " "you have to come here now otherwise I'll hit you, you stupid mother'” (VFö, 2003, 7, p. 109). According to Alfvén, this was because she was going through "one of life's major developmental phases," during which she fluctuated between being a grown up and a minor. She was a grown up while playing but, when something went wrong, she reverted to the thinking of a small child who wanted her mother to have already "understood that and helped her with it before she had said anything." Hence, she still had "the magical belief in mother's and father's 'omnipotence'."

A third phase that was repeatedly outlined, and where the onset was quite clearly defined, occurred when the child was around nine to ten months old, and involved the need for closeness with the parent. For example, "A sad father" had a nine-month-old son who preferred to be held exclusively by his mother. In her response, Alfvén commented that it was common for children around that age to be "extra attached to the mother (mammiga) and in need of being extra close" (VFö, 2006, 2, p. 68). The father had to spend more time alone with the baby so that his son could feel as safe with him as with the mother and learn that he could provide equal protection. Alfvén gave a similar explanation to "Katharina", whose nine-month-old son refused to sleep through the night unless she sat by his bed. The son

\footnotetext{
${ }^{3}$ While Alfvén did not explicitly reference the child psychoanalyst Donald Winnicott and his ideas about infantile omnipotence, there are definite similarities to this notion in Alfvén's answers.
} 
"guards you [the mother]," the psychologist remarked, "so that you will not disappear while he's sleeping ... And when he wakes up, he does so to see that you're still there" (VFö, 2006, 6, p. 106). She stated that this was typical of nine-month-old babies because they realized how vulnerable they were without the parent and feared abandonment.

Children's varied functioning, and the sudden onset of intense fears and fantasies or explosive outbursts, were consistently figured as the result of natural developmental phases and steps, not as signs of pathology stemming from the parents' care. In Alfvén's words: "[t]hat we parents could be the cause of everything bad that our children do and say is one of the silliest trends that has emerged from modern psychology" (VFö, 2003, 7, p. 109). Parents were not to blame for their child's potentially erratic and destructive behaviors; these were at least partly related to natural, and unavoidable, developmental phases.

The notion that children went through stages and phases was certainly not new in psychology (e.g. Jean Piaget's stage theory; see Thompson, Hogan, \& Clark, 2012). What is interesting here is that Alfvén's figuration of children's development as stage-bound led to, and reinforced, a normalization of the problems raised by parents by framing them as healthy and ordinary developmental steps. In contrast to earlier experts, her envisioning of children in terms of stages and phases did not primarily inscribe "a division between normal and abnormal in the form of the differentiation of advanced and retarded" (Rose, 1999, p. 150). Alfvén instead stressed that parents were not to be faulted for everything their child did, removing responsibility from the parents and figuring children's development as somewhat self-directed.

\section{Children as unique individuals}

The two figurations discussed so far both imply that children's problems could be understood and explained in quite general terms: the child acted as she did because she was either a 
particular kind of child or going through a specific developmental phase. Not all of Alfvén's answers, however, encompassed such homogenizing figurations of the child. At times, Alfven framed children as individuals transcending any general developmental theory, and stated that no one - neither parents nor experts - could really know what is best, except for the children themselves. These answers emphasized the figuration of the child as a unique individual.

Here I want to emphasize that the three figurations were not completely separate from one another. Frequently, they appeared side-by-side in a single answer. To illustrate, let us return to "Mother of two's" question, discussed in the Children going through phases and ages section, regarding her daughter who, while playing computer games, yelled at and threatened to hit her mother. Although Alfvén concluded that this rowdy behavior was probably influenced by a specific developmental phase, she also underlined that parents were not the sole cause of children's misbehavior. If that were true, then "the children wouldn't be unique individuals with their very own will and specific way of being. It is of course based on how our children are that we parents have to treat and raise them" (VFö, 2003, 7, p. 109). In this example, the figuration of the child as going through phases appeared alongside the figuration of the child as a unique being, without any apparent contradiction.

Nevertheless, when figuring every child as unique, Alfvén frequently raised the need to acknowledge and adapt to each child's distinctive disposition. This can be seen in the reply to "Worried parents with a wish for hints and advice," who wondered how they could make it easier for their two-and-a-half-year-old daughter to be dropped off at daycare, especially as the personnel had begun to tire of the long, exhausting goodbyes. Alfvén suggested that the parent should actually stay a while longer in the morning to make the transition easier. "In fact," she observed, "we all know that children can't be treated in the same way, so why do 
we so often demand the same thing of every child? ... That is why we must do things differently with different children" (VFö, 2006, 7, p. 97).

Alfvén answered similarly when questioners wanted to know what books to read. When "Skåningen"4 asked for book recommendations on how to create a safe and secure environment for their anxious two-year-old son, Alfvén explained that reading could be useful but "there are no books that can tell [us] about the best environment or upbringing" (VFö, 2003, 12, p. 106). After all, each child was different and had unique needs, so the best strategy was to read several books and "cherry-pick ... what we think specifically suits us and our children." The limits to formal knowledge were likewise highlighted in a response to a question concerning how a 14-month-old child would react to moving house. Humans, Alfvén observed, were not easy to comprehend and "[w]e do not know - neither you, he nor some psychologist - how he will react to the move" (VFö, 2003, 5, p. 107). And in her answer to "Disappointed," who expressed confusion over how to handle her sister-in-law who worked as a pedagogue and constantly criticized how they were raising their child, Alfvén wrote that "it is equally difficult or easy to be a parent, regardless of whether you have knowledge of children or not" $(V F \ddot{o}, 2006,10$, p. 96). According to Alfvén, the most important thing was to respond to "one's own child and that very personality and temperament that this child has."

This figuration clearly implies that each child must be comprehended in their heterogeneity. There were no general methods that worked for every child nor any practical arrangements that suited all children. Neither was it possible to know in advance whether something would be a problem or not, nor to learn exactly how to care for one's own child through reading a book that offers general rules.

\footnotetext{
${ }^{4}$ A “skåning” is a colloquial term for a person from Skåne, a region in southern Sweden.
} 
A second aspect of this figuration is that Alfvén often figured the individual child as knowing what is best for him- or herself. This was particularly noticeable when the question concerned how different choices could influence a child, as when "Separation anxiety," who was separating from their spouse, asked how to best determine the children's living arrangements after the breakup. Should they move houses every other week, or perhaps it was better to have half the week with the father and the other half with the mother? Alfvén responded that this could only be answered by "[t]hose who know best what is good for them," namely "the kids themselves" (VFö, 2005, 5, p. 100). If the parents' arrangements were inadequate, the children would show it "in every possible way. If they eat, sleep and are happy then it's fine." Alfvén answered in a similar fashion to a newly separated father who wondered if his tenmonth-old baby would be affected by sleeping apart from the mother: "try and see how it goes ... The children know what's best for them and we parents notice that" $(V F \ddot{o}, 2006,13$, p. 112). These examples illustrate that, in these instances, Alfvén did not offer any general answer to the question, based for instance on developmental psychology. Instead, she suggested that the "correct" answer could be deciphered through attending to the child's unique physical, psychological and behavioral reactions.

Alfvén also repeatedly claimed that only the child knew when they were ready to take another developmental step. For example, "Cecilia" asked for help in getting her two-yearold daughter to use the potty because she had been warned that potty training needs to start early. Alfvén disagreed and emphasized that there were "certain things that we parents think and hope we can control, but where there really is only one person in charge" $(V F \ddot{o}, 2004,11$, p. 102), that is, the child. She recommended that the parent stop pushing their daughter. "By now," she continued, "she [the daughter] knows what you want. But she will not do as you want until she wants to and can. And she will get to that point quickest if she is allowed to handle it herself." Alfvén reasoned similarly when answering "Ulf," who wanted their four- 
year-old daughter to stop using a pacifier. Although Alfvén thought that it was conceivable to compromise about when to use the pacifier, the best way to help her would be to tell her that "she will herself get to decide when she wants to stop [using it]" but that she should "only use it when she really needs it" (VFö, 2006, 4, p. 97). While it was likely that the daughter would stop using the pacifier once the conflict ended, she nevertheless needed it right now to feel good. "That she knows," Alfvén concluded.

These examples from the advice column highlight how Alfvén portrayed children as very perceptive and capable. Only they knew when the time was right to stop using a pacifier, and no adult prodding could speed up the process. Thus, the problems occupying these parents' minds had almost already been, or soon would be, solved by the child as long as the parents trusted their child's innate abilities.

Like the other two figurations, figuring children as unique selves has a history. The "romantic developmentalism" of the $18^{\text {th }}$ century framed children as individuals with an authentic and "robust selfhood" (Ryan, 2008, p. 570) and, for a comparison closer to our time, T. Berry Brazelton argued that children are competent individuals who can actually guide their parents, as long as they learn to listen to their baby's own form of communication (Hulbert, 2004). And, as Johansson (2007) has noted, the child has frequently, and over time also increasingly, been framed in $V F \ddot{o}$ as a competent person, even from a very early age. But my analysis adds to, and nuances, Johansson's conclusion by showing how this figuration coexisted alongside the two aforementioned ones. So, while articles in $V F \ddot{o}$, including Alfvén's column, did discuss children in such individualized terms, they were also at the same time defined in other ways, such as being a particular kind of child, with quite different implications for how to understand both children's development and perceived childhood problems and their solutions. 


\section{Alfvén's naturalized figuration of the child in an historiographical context}

In this article, I have analyzed the answers given by child psychologist Malin Alfvén to parents writing to the Swedish parenting magazine Vi Föräldrar during the period 20032008. A central finding was that Alfvén consistently framed the child-related problems raised in these letters as transient, natural and holding educational and developmental value for both parents and child. The analysis further shows that Alfvén's answers were underpinned by three different figurations of - or ways of defining - the child that made children's odd, destructive or worrisome behavior explicable and intelligible: the child as being a particular kind of child (e.g. sensitive, shy and observant); as going through developmental phases and ages; and as a unique individual. Through these three figurations, Alfvén naturalized the issues brought up in the letters and placed them in a nonmedical frame of reference where, for instance, emotional instability was not seen as a sign of disorder but as an effect of the child going through a developmental phase. To further contextualize the findings presented in this article, I will now consider the similarities and differences between the three figurations, position Alfvén vis-à-vis other "child psy" experts in Sweden and then discuss some of the historiographical implications of this article.

Drawing on what is in the history of psychology the quite common (but nowadays also quite problematic, see e.g. Keller, 2010) distinction between "nature" and "nurture", I would argue that Alfvén did not really maintain that "nurture" predominantly affects how children turn out, meaning that she did not position the child's environment as the main developmental factor. But neither did she simply offer a straightforward naturalization. Instead, the analysis shows how Alfvén's figurations rather encompassed three naturalizing configurations, which can be further described by attending to how each figuration framed children and their development in terms of being either homogenous or heterogeneous, permanent or impermanent. 
The Particular kinds of children figuration implied homogeneity within each kind but heterogeneity between kinds. Children who were, for instance, shy and introverted resembled each other psychologically and constitutionally and demanded similar care, but they differed from temperamental and willful children. Being a particular kind of child was, moreover, not a temporary state. Rather, the child's basic characteristics and tendencies were presented as permanent and not modifiable by childhood experiences.

The figuration of the child going through developmental phases and ages, on the other hand, strongly stressed impermanence. How children functioned and behaved at a particular moment depended on whether they were currently going through a specific stage. This figuration was characterized by a multifaceted configuration of sameness and difference, as the homogeneity of children depended on their going through the same developmental phase. Whereas two children going through the same defiant period would act alike, their behavior would differ from that of a child who was not currently in that phase. But the phases and ages figuration additionally implied a general homogeneity between children since they would all someday go through similar phases. The homogeneity entailed in the universality of stages and ages over a longer period of time thus intersected with the heterogeneity at each particular time that existed between children undergoing specific phases.

The third figuration - the child as a unique individual - was characterized by a thoroughgoing heterogeneity. In this figuration, there were no profound similarities between children, at least not concerning aspects that were really relevant to consider. Neither was it possible to discuss children in general theoretical terms. Instead, each child had to be comprehended in and through their particularity. The importance of this particularity was, furthermore, permanent in that it did not change over time. There was no point at which the child transformed from a particular, irreducible individual into a "general" child. 
There are important distinctions to be made between the figurations of the child as a particular kind and as stage-bound, on the one hand, and that of children as unique individuals on the other. One significant difference is that the former two implied that children's development was deterministic and predictable, whereas the latter stressed its idiosyncrasies. Yet, despite this, all three figurations presented the matter of children's development as principally following a natural, autonomous trajectory that zigzags between permanent and impermanent paths, and upon which parents have little effect.

This position is rather different from that which has been held by many other Swedish experts. Descriptions of children as fragile beings whose developmental process could be disturbed by maladjusted early experiences with caretakers can be found in child psychotherapy books from the 1970s (Zetterqvist Nelson, 2017), and Swedish child healthcare professionals have likewise mainly attributed children's “developmental delays" to a lack of stimulation and attention on the parents' part (Hörnfeldt, 2009). Furthermore, experts contemporaneous with Alfvén strongly emphasized the important role that parents played in their child's well-being, including how they can detrimentally affect the child's development and health (Assarsson \& Aarsand, 2011; Dahlstedt \& Fejes, 2014).

Alfvén offered quite conflicting figurations of the child, in which they were not as frail and vulnerable as these experts claimed. Nor did parents' care determine their child's development. But the question is how to understand both Alfvén's general viewpoint and her position in the Swedish media landscape. We can start by considering Alfvén's relation to $V F \ddot{o}$ as an outlet, because it was through this magazine that she consistently had the opportunity to circulate her views on children to the Swedish public for several decades. $V F \ddot{o}$ was founded in the late 1960s with the ambition of highlighting children as individuals, and research has shown that the magazine consistently presented children as subjects in their own right rather than being in a subordinate role to adults (Möllerström et al., 2013). Furthermore, 
experts featured in $V F \ddot{o}$ often explained and commented on topics in a generally quite cautious manner that deferred to parents' own understanding of their child. VFö's general perspective on the child as an individual who can be understood through scientific, but cautiously interpreted and applied, theories fits quite well with Alfvén's notion of the natural, sturdy, self-correcting child - even though her version had rather more far-reaching implications. VFö's orientation may therefore help explain how Alfvén was able for several decades to circulate a form of "child psy" expertise which disagreed with that of many past and contemporaneous Swedish experts.

Alfvén's figurations can additionally be placed against the backdrop of two notions of the child that started to gain traction in Nordic countries during the late $20^{\text {th }}$ and early $21^{\text {st }}$ centuries (although they can definitely also be discerned elsewhere), namely the competent child (Sandin, 2003) and the resilient child (Sommer, 2008). While these certainly deserve a more in-depth treatment than is possible here, I do want to highlight that Alfvén's figurations of the child partly overlap with these two views, although she never explicitly referenced them. Alfvén's general emphasis on the benign unfolding of the child's natural development did imply that children had certain inborn capabilities that would reveal themselves with time, without parents needing - or being able - to influence the process. Children were likewise often presented as knowing and being able to do more than their parents imagined. So, although the competence that Alfvén's figurations encompass might not fully mirror that which was assumed in, for example, political discussions about children's rights, a version of it still underpinned much of her advice.

Second, the natural unfolding of the child, which Alfvén considered it difficult to permanently disturb, led to a figure of the child characterized by resilience. While children might encounter difficulties and challenges - be it from parents, other children or developmental vicissitudes - Alfvén seems to have seldom doubted that they would be able 
to withstand these without any enduring harm being done. Although Alfvén's figurations might thus have clashed with claims made by certain other Swedish "child psy" experts and professionals, there are connections to be made with broader notions of the child that were circulating during the time period in question and which, at least partly, supported Alfvén's framing of childhood.

Furthermore, I want to consider Alfvén in relation to non-Swedish experts, particularly because some of the best-known "child psy" experts have delivered equally tempering advice. Besides Benjamin Spock's famous mantra that parents should simply trust themselves and realize that they know more than they think, during the 1950s Bowlby encouraged readers of Parent not to worry too much about what experts said and simply allow their love for their child to guide them (Thomson, 2013). And for almost two decades Brazelton emphasized that babies certainly could endure parents' mistakes and misunderstandings (Hulbert, 2004). In this regard, Alfvén was not unique. But it is worth noting that most of these experts were active during the mid- $20^{\text {th }}$ century. Since then, there have been several shifts in how children's development and health have been conceptualized. For instance, many later experts have strongly emphasized the importance of parents stimulating the cognitive dimension of children's development (Quirke, 2006; Wrigley, 1989), including Brazelton, who in a book published in 2000 outlined a relatively fixed training schedule (Hulbert, 2004).

This development has intensified over the last two decades, perhaps particularly in the NorthAmerican context, with the advent of "neuro" frameworks and theories in the advice literature (Hardyment, 2007; Macvarish, Lee, \& Lowe, 2014; Wall, 2004). These have often coupled the older concern with children's development, and particularly its cognitive aspects, with newer notions of how the brain grows during infancy and parents' role in promoting optimal brain development. Alfvén's advice did not center at all on the child's brain, either as 
a foundation for explaining the child's development or as a target for change through parents' actions and care. Her stance thus went against the entire project of the emerging "neuro" advice literature, with its notion of the child as being, if not fragile, then at least highly moldable.

Swedish historical studies have discerned a different attitude among Swedish experts towards neuropsychological and neuropsychiatric explanatory frameworks than seems to be the case among their North American colleagues, for instance. Zetterqvist Nelson (2003) discusses how, during the late 1990s and early 2000s, Swedish experts and politicians subordinated neuropsychiatric ways of thinking to a public-health perspective whose main focus was on broad interventions aimed at all Swedish children. Skagius (2019) likewise found that Swedish experts drew on neuropsychological and neuropsychiatric theories and concepts when discussing children's health and development, but did so while still emphasizing the importance of attending to social and political factors in exacerbating mental distress. There is thus a pattern of Swedish experts configuring and mobilizing neuropsychological and neuropsychiatric expertise in a way that differs starkly from that of North American experts. So, while many Swedish psychological and psychiatric experts would probably not fully concur with Alfvén, considering that she never made any references to the brain's significance in childhood matters, it is at least possible to see a shared mistrust of wholly individualized, neurological explanations (see also Hörnfeldt, 2009).

To sum up, in her column Alfvén presented advice that figured children as sturdy, selfcorrecting and developing according to a natural trajectory that parents could not really affect but simply had to trust. While Alfvén's pragmatic and non-theoretical approach may account for some of her popularity (cf. Shapira's [2017] discussion of Susan Isaacs), it does make it more difficult to untangle which "child psy" theories and notions of the child underpinned her advice and to chart the various expert and professional networks of which she was part. In 
this article, I have tried to offer some possible understandings of what may have influenced her by pointing to the history of the "psy" sciences, to certain notions of the child that were prominent in the Nordic countries, and to the orientation of $V F \ddot{o}$ as a magazine. Much more work is certainly needed in this regard, however, including analyses of Alfvén's books and radio shows.

Moreover, the analysis has focused on an advice column written by a single child psychologist over a rather short period. I am therefore wary of drawing overly generalized conclusions. Yet, I would argue that my findings can help create a space to think about and reflect on the historiography of children's mental health. Both Swedish and international scholars, as well as those from the history of childhood and the history of the "psy" sciences, have repeatedly claimed that childhood in the $20^{\text {th }}$ and early $21^{\text {st }}$ centuries was increasingly characterized by medicalization (and/or psychiatrization,) and "riskification" and that discussions of children's development were dominated by the notion of "parental determinism".

This article can be seen as an attempt to respond to Pettit's appeal, mentioned in the introduction, for more detailed analyses and mappings of the "psy" sciences, with the hope of problematizing some of these sweeping and general statements about the history of childhood and, in particular, the role played by, and historically attributed to, "child psy" experts. While some of these experts have undoubtedly participated in framing childhood in such a medicalized, "riskified" manner, others have not. Instead, they have been part of other networks of circulation within which children have been construed in a different manner, with different implications for how readers, such as parents, are expected to understand and care for them. 
This article has presented one such counter-example, featuring a publicly and professionally renowned expert who offered a quite different version of childhood, characterized by a benign and robust development that outside forces could scarcely affect. Alfvén's way of responding - whereby she often discussed and moved between different figurations of the child in a single answer to a question - implies that there was seldom only one specific answer to parents' questions. A child's development and health were difficult to predict, Alfvén stated, even for an expert, and parents needed to be open to a range of possibilities and solutions. It was an uncertain business, and not only because she was a remote expert, answering questions about children she had never met or talked to; uncertainty seemed rather to be inherent to childhood itself. This, I argue, was the most prominent normativity in the way in which Alfvén coordinated and balanced the different figurations: tolerate uncertainty, both epistemologically and developmentally, and have trust in yourself as parents and in your child.

\section{Conclusion}

I have argued above that it is important to consider material from the public sphere when exploring the history of the "psy" sciences as it may complement the more common analytical focus on scientific and political documents. In this article, I examined one advice column featured in the Swedish parenting magazine Vi Föräldrar (Us Parents) during the period 2003-2008, in which the child psychologist Malin Alfvén answered questions sent in by readers. I contended that Alfvén generally framed the perceived child problems brought up in the submitted letters as transient, ordinary and, quite often, even beneficial. They were just part of the child's natural development, not a sign of, say, a psychiatric disorder.

Drawing on concepts from the history of childhood, I argued that Alfvén's naturalizing and normalizing reasoning can be discerned as underpinned by what I have called three different child figurations: the child as being a particular kind of child, as going through phases and 
ages, and as a unique individual. While each of these had quite different implications for how to conceive of children and their development, they all emphasized that children will mainly develop on their own according to their natural inclinations. Alfvén thus offered a figuration of children's development as something that parents mostly had to accept and endure - and in which they could also place their trust.

The importance of this analysis is two-fold. First, it offers a counterexample to the many historiographical claims that childhood is increasingly medicalized (particularly psychiatrized) and that children's development is often positioned as being almost fully determined by parents' care. Moreover, child experts, such as psychologists and psychiatrists, are said to have played a major role in this historical shift. The aim of this article is not to dismantle such broad claims, but to nuance them by showing that the circulation of "child psy" expertise in the public sphere may be more complex and multifaceted than is often assumed. Secondly, this article also represents an attempt to close the gap between the history of the "psy" sciences and the history of childhood, as these fields have not intersected to any great extent despite, I would argue, potentially having much to offer each other. In this article, I have achieved this through integrating literature from both fields as well as drawing my analytical vocabulary from the latter.

\section{References}

Alfvén, M., \& Hofsten, K. (2001). Trotsboken [The Defiance Book]. Stockholm: Bonnier Carlsen.

Apple, R. D. (2006). Perfect motherhood: Science and childrearing in America. New Brunswick, NJ: Rutgers University Press.

Assarsson, L., \& Aarsand, P. (2011). "How to be good": Media representations of parenting. Studies in the Education of Adults, 43(1), 78-92. 
Beatty, B., Cahan, E. D., \& Grant, J. (Eds.). (2006). When science encounters the child: Education, parenting and child welfare in 20th-century America. New York: Teachers College Press.

Beauvais, C. (2016). Ages and ages: The multiplication of children's "ages" in early twentieth-century child psychology. History of Education, 45(3), 304-318.

Billington, T. (1996). Pathologizing children: Psychology in education and acts of government. In E. Burman, G. Aitken, P. Alldred, R. Allwood, T. Billington, B. Goldberg, ... S. Warner (Eds.), Psychology discourse practice: From regulation to resistance (pp. 37-54). London: Taylor \& Francis.

Bonniers Tidskrift. (n.d.). Historik [History]. Retrieved from http://bonniertidskrifter.se/omoss/historik/

Börjesson, M. (1999). A newspaper campaign tells: The launch of neuro-psychiatric diagnoses in the Swedish daily press 1997-1999. Scandinavian Journal of Disability Research, 1(2), 3-25.

Börjesson, M., \& Palmblad, E. (Eds.). (2003). Problembarnets århundrade - normalitet, expertis och visionen om framsteg [The century of the problem child - Normality, expertise and the vision of progress]. Lund: Studentlitteratur.

Burman, E. (2008). Deconstructing developmental psychology. New York: Psychology Press.

Castañeda, C. (2002). Figurations: Child, bodies, worlds. London: Duke University Press.

Clarke, J. N. (2010). The domestication of health care: Health advice to Canadian mothers 1993-2008 in today's parent. Family Relations, 59(2), 170-179.

Clarke, J. N. (2011). Childhood depression and mass print magazines in the USA and Canada: 1983-2008. Child and Family Social Work, 16(1), 52-60. 
Clarke, J. N. (2014). Tracking governance: Advice to mothers about managing the behaviour of their children in a leading Canadian women's magazine during two disease regimes. Critical Public Health, 24(3), 253-265.

Clarke, J. N., \& Mosleh, D. (2015). Risk and the Black American child: Representations of children's mental health issues in three popular African American magazines. Health, Risk \& Society, 17(1), 1-14.

Clarke, J. N., Mosleh, D., \& Janketic, N. (2016). Discourses about children's mental health and developmental disorders in North American women's magazines 1990-2012. Child \& Family Social Work, 21(4), 391-400.

Dahlstedt, M., \& Fejes, A. (2014). Family makeover: Coaching, confession and parental responsibilisation. Pedagogy, Culture \& Society, 22(2), 169-188.

Gleason, M. (1996a). Disciplining children, disciplining parents: The nature and meaning of advice to Canadian parents, 1945-1955. Histoire Sociale/Social History, 29(57), 187209.

Gleason, M. (1996b). Normalizing the ideal: Psychology, the school, and the family in postWorld War II Canada, 1945-1960. Ph.D Diss., University of Waterloo, Canada.

Hardyment, C. (2007). Dream babies: Childcare advice from John Locke to Gina Ford. London: Frances Lincoln.

Hedman Bergström, E., \& Duregård, A. (2009). Temanummer: Bilden av Familjen i tidskriften Vi Föräldrar [Thematic issue: The image of the family in the magazine Vi Föräldrar], Judith. Feministiskt mediekritiskt magasin. Göteborg: Göteborgs universitet.

Hörnfeldt, H. (2009). Prima barn, helt ua: normalisering och utvecklingstänkande i svensk barnhälsovård 1923-2007 [First class child; no remarks: Normalisation and 
developmental thinking in Swedish health care 1923-2007]. Göteborg: Makadam förlag \& bokproduktion $\mathrm{AB}$.

Hulbert, A. (2004). Raising America: Experts, parents, and a century of advice about children. New York: Vintage Books.

Johansson, T. (2007). Experthysteri: kompetenta barn, curlingföräldrar och supernannies [Expert hysteria: Competent children, curling parents and super nannies]. Stockholm: Atlas.

Keller, E. F. (2010). The mirage of a space between nature and nurture. Durham: Duke University Press.

Lee, E. (2014). Experts and parenting culture. In E. Lee, J. Bristow, C. Faircloth, \& J. Macvarish (Eds.), Parenting culture studies (pp. 51-75). Basingstoke: Palgrave Macmillan.

Lee, E., Bristow, J., Faircloth, C., \& Macvarish, J. (Eds.). (2014). Parenting culture studies. Basingstoke: Palgrave Macmillan.

Littmarck, S. (2017). Barn, föräldrar, välfärdsstat: Den politiska debatten om föräldrautbildning och föräldrastöd 1964-2009 [Children, parents, welfare state: The political debate about parent education and parenting support 1964-2008]. Ph.D Diss., Linköping University, Linköping.

Macvarish, J., Lee, E., \& Lowe, P. (2014). The "First Three Years" Movement and the Infant Brain: A Review of Critiques. Sociology Compass, 8(6), 792-804.

Mechling, J. (1975). Advice to historians on advice to mothers. Journal of Social History, $9(1), 44-63$.

Milkie, M. A., \& Denny, K. E. (2012). Changes in the cultural model of father involvement: Descriptions of benefits to fathers, children, and mothers in parents' magazine, 19262006. Journal of Family Issues, 35(2), 223-253. 
Möllerström, V., Sandberg, H., \& Ringsberg, K. C. (2013). Medier och barns hälsa. Från peppning och glamour till trygg vägledning. En diskursanalys av två föräldramagasin [Media and children's health. From encouragement and glamour to safe guidance. A discourse analysis of two parenting magazines]]. Nordiska ministerrådets förlag.

Norstedts. (n.d.). Malin Alfvén. Retrieved from http://www.norstedts.se/forfattare/116383malin-alfven

Pettit, M. (2015). Subject matter: Human behavior, psychological expertise, and therapeutic lives. Social Studies of Science, 45(1), 146-158.

Psykologtidningen. (2011). Malin Alfvén får stora Psykologpriset [Malin Alfvén receives the Grand Psychologist Prize]. 9, 4-6.

Quirke, L. (2006). “Keeping young minds sharp”: Children's cognitive stimulation and the rise of parenting magazines, 1959-2003. Canadian Review of Sociology \& Anthropology, 43(4), 387-406.

Richter, S., \& Ursholm, J. (2009). Bland minigrisar \& välling - En undersökning av hur pappan framställs i svenska föräldratidningar [Among miniature pigs and gruel - A study of how the father is portrayed in Swedish parenting magazines]. Göteborg: Göteborgs universitet.

Rose, N. (1991). Experts of the soul. Psychologie Und Geschichte, 3(1/2), 91-99.

Rose, N. (1999). Governing the soul: The shaping of the private self. London: Free Association Books.

Ryan, P. J. (2008). How new is the "new" social study of childhood? The myth of a paradigm shift. Journal of Interdisciplinary History, 38(4), 553-576.

Sandin, B. (2003). Barndomens omvandlig - från särart till likart [The transformation of childhood - From difference to similarity]. In B. Sandin \& G. Halldén (Eds.), Barnets bästa - en antologi om barndomens innebörder och välfärdens organisering [In the 
best interest of the child - An anthology on the meanings of childhood and the organisation of the welfare] (pp. 221-240). Stockholm: Brutus Östlings Bokförlag Symposion.

Sandin, B. (2014). History of children's well-being. In A. Ben-Arieh, F. Casas, I. Frønes, \& J. E. Korbin (Eds.), Handbook of child well-being: Theories, methods and policies in global perspective (pp. 31-86). New York: Springer

Seifarth, S. (2007). Råd i radion: Modernisering, allmänhet och expertis 1939-1968 [Advice on the radio: Modernization, publics and expertise 1939-1968]. Stockholm: Carlsson.

Shapira, M. (2013). The war inside: Psychoanalysis, total war, and the making of the democratic self in postwar Britain. Cambridge: Cambridge University Press.

Shapira, M. (2017). "Speaking Kleinian”: Susan Isaacs as Ursula Wise and the inter-war popularisation of psychoanalysis. Medical History, 61(4), 525-547.

Skagius, P. (2019). Brains and psyches: Child psychological and psychiatric expertise in a Swedish newspaper, 1980-2008. History of the Human Sciences, 32(3), 76-99.

Sommer, D. (2008). Barndomspsykologi: utveckling i en förändrad värld [Childhood psychology: Development in a changing world]. Malmö: Liber.

Stearns, P. N. (2003). Anxious parents. New York: New York University Press.

Thompson, D., Hogan, J. D., \& Clark, P. M. (2012). Developmental psychology in historical perspective. Malden: Wiley-BlackwellPublisher.

Thomson, M. (2006). Psychological subjects: Identity, culture, and health in twentiethcentury Britain. Oxford: Oxford University Press.

Thomson, M. (2013). Lost freedom: The landscape of the child and the British post-war settlement. Oxford: Oxford University Press.

Timimi, Sami. (2014). Pathological child psychiatry and the medicalization of childhood. London: Taylor and Francis. 
Turmel, A. (2008). A historical sociology of childhood: Developmental thinking, categorization and graphic visualization. Cambridge: Cambridge University Press.

Wall, G. (2004). Is your child's brain potential maximized? Mothering in an age of new brain research. Sociology Faculty Publications, Paper 7.

Wall, G. (2018). “Love builds brains": Representations of attachment and children's brain development in parenting education material. Sociology of Health \& Illness, 40(3), $395-409$.

Ward, S. (1996). Filling the world with self-esteem: A social history of truth-making. Canadian Journal of Sociology, 21(1), 1-23.

Wrigley, J. (1989). Do young children need intellectual stimulation? Experts' advice to parents, 1900-1985. History of Education Quarterly, 29(1), 41-75.

Zetterqvist Nelson, K. (2003). Debatten om bokstavsdiagnoser - en kamp om politiskt inflytande [The debate about letter diagnoses - A struggle over political influence]. In B. Sandin \& G. Halldén (Eds.), Barnets bästa. En antologi om barndomens innebörder och välfärdens organisering [In the best interest of the child - An anthology on the meanings of childhood and the organisation of the welfare] (pp. 101-137). Eslöv: Brutus Östlings Bokförlag Symposion.

Zetterqvist Nelson, K. (2017). The changing construction of the child figure in literature on child psychotherapy in Sweden 1945-1975. In J. Ahlbeck, P. Lappalainen, K. Launis, \& K. Tuohela (Eds.), Childhood, literature and science: Fragile subjects (pp. 68-79). London: Routledge. 


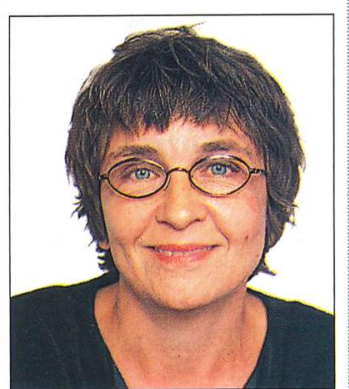

Malin Alfvén

är psykolog inom mödra- och barnhälsovården.

Du kan fråga henne om ditt föräldraskap om barnuppfostran och om familjerelationer. Skriv till

Vi Föräldrar,

"Fråga Malin" 10544 Stockholm eller mejla på fragamalin@vf.bonnier.se Du får gärna vara anonym i tidningen men bifoga alltid namn, adress och telefonnummer! Tyvärr kan Malin Alfvén inte besvara alla brev.

\section{"Vad din son} gör, då han blir så arg, är att visa dig sin kärlek. Det är dig han utmanar, dig han pressar till den yttersta gränsen."

\section{Ska vår bebis sova i eget rum?}

Vi ska flytta och jag undrar om det är okej att lägga vårt barn på 10 månader i eget rum direkt. Eller ska han fortsätta sova i vårt rum (i egen säng, som han gör nu) tills han känner sig hemma i det nya huset?

Tack på förhand

Malin Alfvén: Mitt svar blir: pröva! Om ni gärna vill att han sover i eget rum, så passa på att lägga honom i det egna rummet redan från början. Han kommer att "berätta" för er var han vill sova. Sover han bra, så är det bra för honom, men blir han orolig av flytten, så kommer ni att ta in honom i ert rum igen under en period, så att han får vänja sig. Men även om det går bra en period i det egna rummet, så är risken ändå stor att han hamnar i er säng igen. För det är så de gör, de allra flesta av våra älskade ungar. När det händer mycket i deras liv eller i deras utveckling behöver de vara nära oss även på nätterna.

\section{Varför har hon mardrömmar?}

Min 6-åriga dotter har alltid sovit bra hela nätterna, men har nu börjat drömma mycket mardrömmar. Hon vaknar nästan varje natt och har svårt att somna om. Hon är ett tryggt barn i vanliga fall. Nu undrar jag om det är vanligt att barn i den här åldern börjar drömma mycket? Hon har börjat sexårsverksamheten, trivs jättebra och verkar inte ha några problem med kompisar eller personal. Är detta bara en fas som de flesta 6-åringar går igenom?

\section{Undrande}

Malin Alfvén: Hon håller på att bli stor nu, din lilla 6-åring. Hon befinner sig i den fas i livet som vi kallar "lilla tonåren". En fas då det händer massor i själen och kroppen. Då vi verkligen börjar kunna ta till oss allt hemskt som händer - inte bara med oss själva - utan också med mamma och pappa och andra nära. Världssamvetet vaknar, djurens lidande förstår vi, orättvisorna blir tydligare och döden blir verklighet för oss.

Samtidigt blir många 6-åringar klumpiga och får svårt att sitta still.
Kort sagt, livet blir ganska kaotiskt under en period. Så mycket händer i oss att vi måste ta natten till hjälp. Vi drömmer mardrömmar. Vi vaknar och är rädda och då finns räddningen hos mamma och pappa och helst i deras säng. Den här första "tonårsperioden" går över efter ett tag. Och då har vi ett mognare och i många avseenden mer "vuxet" barn i familjen. Utveckling och kaos hör ihop med oberoende om vi är trygga och harmoniska. Det är något vi alla går igenom mer eller mindre tydligt. Något som är nödvändigt för att vi ska mogna och utvecklas. Du kan läsa mer om dessa perioder i Trotsboken som jag skrivit ihop med Kristina Hofsten.

\section{Har mitt barn adhd?}

Har en son på 15 månader som kom till genom en IVF-behandling. Efter många år av barnlöshet fick vi äntligen vårt älsklingsbarn och vi är otroligt tacksamma trots att vi inte fått sova en hel natt sedan han kom. Det är jag som är uppe med honom, eftersom min man kör lastbil och behöver sömnen mer än jag. Vi har prövat theralen och lergigan, lugnande medel som kan hjälpa mot sömnrubbningar hos barn. Men de gav inget resultat, utan problemen förvärrades. I dag kör vi honom över tröskeln i sin vagn och lägger in honom $\mathrm{i}$ vår säng. I regel vaknar han bara en gång per natt.

Han har alltid haft hett temperament, men nu kan han bli så arg att det inte går att nå honom. Han kan skrika nonstop i 45 minuter tills han kräks. Nu vet jag inte hur jag ska göra. Förut lät jag honom vara tills han lugnat ner sig, men utbrotten blir ju bara längre och längre. Har försökt visa in honom på rummet, men det blir bara värre. Jag är så trött, rasar i vikt, har ont $\mathrm{i}$ öronen och $\mathrm{i}$ kroppen. Hur får jag kontroll över vår situation?

Han går i förskolan och trivs bra där. De undrar om han alltid är så go och glad. Han är väldigt mammig, hela bördan ligger på mig. Han är ett väldigt aktivt barn och har alltid varit det. Jag har börjat undra om han har adhd, som sin pappa. Min son är i övrigt en stor, välväxt pojke som är frisk för det mesta. Mitt hopp står till dig ...
Malin Alfvén: Först vill jag säga dig: Du gör inte något fel! Vad din son gör, då han blir så arg, är att visa dig sin kärlek. Det är dig han utmanar, dig han pressar till den yttersta gränsen. Det gör han för att han vet hur mycket du älskar honom och för att han älskar och litar så mycket på dig. Det är av dig han vill ha motstånd. I förskolan finns inte de här starka känslorna och då visar han andra sidor. Precis som vi vuxna också gör, egentligen. På jobbet skärper vi oss, men hemma kan vi visa alla våra känslor.

Typiskt för de här envisa, viljestarka och krävande barnen är att de ofta krånglar med nattsömnen. Efter att ha prövat allt, har ni nu lyckats hitta ett sätt att få honom att sova som ni alla tre kan acceptera. Det tycker jag är fantastiskt.

Och nu till hans utbrott som har gjort dig helt slut. Så här tänker jag: Tala med grannarna och berätta om er envisa son med sitt heta temperament. Det tar emot, men det hjälper både er och dem. Jag tror att du behöver "time out" från din son. Har du möjlighet att åka bort ett par dagar och lämna far och son hemma själva? Far och son behöver det också, tänker jag. Så att de lär känna varandra, utan att du finns i närheten.

Vad vi ofta gör, då vi har så här viljestarka barn, är att vi försöker lirka och tala med dem för att undvika konflikterna. Ibland kan det vara bättre att som vuxen vara mera rakt på. När du vet att ni måste göra något eller att han inte får göra något, så tar du ett ordentligt tag i honom, ser honom bestämt i ögonen och säger bara "Nej, du får inte!" eller "Nu måste vi gå!". Ingen diskussion, inget lirkande.

Det är du som bestämmer. Han kommer att fortsätta att vråla en period, men inte lika ofta och inte lika länge. Och framför allt kommer du inte bli lika trött.

Hans beteende i förskolan talar emot adhd. Barn med adhd är särskilt lättprovocerade i större grupper. Och för din son är det ju precis tvärtom.

När man känner att man inte kommer vidare kan man göra som du, det vill säga att skriva. Man kan också tala med någon utomstående, till exempel psykologen på bvc. Hon/han har erfarenhet av barn som är som er son, hur det är att vara förälder till ett sådant barn och hur jobbigt det är. 